\title{
PENGARUH PERENCANAAN PAJAK TERHADAP MANAJEMEN LABA YANG DIMODERASI OLEH PENURUNAN TARIF PAJAK (DISKON PAJAK)
}

\author{
Oma Romantis ${ }^{1}$, Kurnia Heriansyah ${ }^{2}$, Soemarsono D. $W^{3}$, Widyaningsih Azizah ${ }^{4}$ \\ Fakultas Ekonomi dan Bisnis Universitas Pancasila \\ romealexander700@gmail.com $^{1}$
}

\begin{abstract}
The aims of this study to examine the effect of tax planning on earnings management which is moderated by reducing tax rates (tax discounts). The population in this study are companies listed in the 2017-2018 LQ45 index. The sampling technique in this study used a purposive sampling method with predetermined criteria, in order to obtain a total sample of 23 companies with final data totaling 46 financial statements. The type of data is secondary data obtained from www.idx.co.id. The analysis technique used in this study is panel data regression analysis and is processed using the Eviews 9.0 program. The results of this study indicate that tax planning has a significant effect on earnings management with a negative coefficient direction. A reduction in tax rates (tax discounts) weakens the effect of tax planning on earnings management.
\end{abstract}

Keywords : $\quad$ Tax Planning, Tax Reducting Rates (Tax Discounts), Earnings Management

\section{PENDAHULUAN}

Perusahaan didirikan dengan tujuan untuk memperoleh laba seoptimal mungkin. Pemilik perusahaan biasanya menyerahkan sumberdaya yang dimiliki perusahaan untuk dikelola oleh manajemen. Dengan demikian, manajemenlah yang nantinya akan bertanggung jawab kepada pemilik perusahaan untuk melaporkan kegiatan pengelolaan sumberdaya tersebut melalui sebuah laporan keuangan. Laporan keuangan tersebut merupakan cerminan dari hasil kinerja manajemen dalam mengelola perusahaan. Pengguna laporan keuangan seperti stakeholder dan manajer perusahaan membutuhkan laporan keuangan untuk pengambilan keputusan karena di dalam laporan keuangan terdapat informasi-informasi mengenai perusahaan terutama dari segi keuangan perusahaan. Dalam pengelolaannya, perusahaan memperhatikan setiap hal yang dianggap penting karena mempengaruhi kinerja manajemen. Salah satunya terkait dengan pembebanan pajak penghasilan atas laba yang diperoleh oleh perusahaan (Hamijaya, 2015:2).

Pemerintah menerima pendapatan yang besar dari sektor pajak. Maka dari itu, pemerintah berusaha mekasimalkan pendapatan dari sektor pajak melalui undang-undang perpajakan. Disisi lain, manajer yang mengelola perusahaan menginginkan pembayaran pajak sekecil mungkin. Perbedaan kepentingan antara pemerintah dan manajemen itulah yang pada akhirnya membuat manajer akan melakukan berbagai cara agar dapat membayar pajak seminim mungkin. Maka tidaklah heran jika sering kali manajer melakukan manajemen laba yang salah satunya dilakukan dengan cara perencanaan pajak.

Sulistyanto (2014:51) menyatakan manajemen laba merupakan (earnings management) merupakan aktivitas manajerial untuk mempengaruhi dan mengintervensi laporan keuangan dengan menggunakan metode akuntansi yang diterima dalam Prinsip Akuntansi Berterima Umum (PABU). Istilah manajemen laba digunakan untuk menyebut praktik akuntansi yang tidak melanggar aturan.

Alasan penulis memilih manajemen laba sebagai variabel dependen adalah karena manajemen laba seolah-olah sudah menjadi kebiasaan bagi perusahaan di seluruh dunia. Akibatnya dari manajemen laba ini bukan hanya merusak tatanan perekonomian saja, tetapi juga merusak etika dan moral. 
Fenomena manajemen laba yang baru-baru ini terjadi pada perusahaan otomotif Toyota. Tokyo, Kompss.com - Laba raksasa otomotif Jepang Toyota merosot untuk pertama kalinya dalam lima tahun. Padahal, Toyota telah menjual lebih banyak mobil pada kuartal I 2017 dibandingkan tahun 2016 lalu. Mengutip BBC pada hari Kamis (11/5/2017), Toyota mengakui bahwa merosotnya laba disebabkan oleh tingginya biaya dan fluktuasi nilai tukar. Laba Toyota pada kuartal I 2017 tercatat sebesar 1,83 triliun yen atau 16,1 miliar dollar AS. Angka tersebut turun 21 presen dibandingkan laba pada kuartal I 2016. Pihak manajemen Toyota pun telah memperingatkan bahwa laba pada tahun 2018 mendatang akan lebih rendah. Ini disebabkan oleh menguatknya nilai tukar Yen Jepang. Prediksi Toyota tersebut didasarkan pada proyeksi bahwa nilai tukar Yen akan berada di sekitar level 105 per dollar AS hingga Maret 2018 mendatang. Level tersebut melemah dibandingkan 108 pada tahun finansial lalu. Toyota telah kehilangan statusnya sebagai produsen mobil dengan penjualan tertinggi. Status tersebut kini disandang oleh pabrikan mobil asal Jerman, Volkswagen.

Toyota telah menjual 10,25 juta unit mobil pda kuartal I 2017, lebih tinggi dibandingkan 10,19 juta unit pada periode yang sama tahun sebelumnya. Akan tetapi, pendapatan dari penjualan mobil pada kuartal I 2017 malah turun menjadi 27,6 triliun Yen. Toyota kini berada dalam perjuangan untuk mempertahankan bisnisnya di Amerika Serikat, yang merupakan pasar terbesarnya. Penjualan anjlok di Amerika Utara karena Toyota susah payah memenuhi permintaan akan mobil yang lebih besar, seperti sport utility vehicle (SUV) yang menjadi lebih murah untuk dikemudian karena harga bahan bakar minyak (BBM) yang lebih murah (https://money.kompas.com/read/2017/05/11/10020 0826/laba.toyota.anjlok.untuk.pertama.kali.dalam.5 tahun).

Fenomena lain dalam manajemen terjadi pada PT. Toshiba. Pimpinan puncak PT. Toshiba Corporation terlibat secara "sistematis" dalam skandal penggelembungan keuntungan perusahaan sebesar 1,2 miliar Dollar AS selama beberapa tahun (Kompas.com, 21 Juli 2015). Berdasarkan hasil investigasi, diketahui tindakan penggelembungan laba tersebut dilakukan karena PT. Tosbiba gagal mencapai terget keuntungan ditambah lagi krisis global yang melanda pada waktu itu. Tindakan penggelembungan laba tersebut membuat CEO Hisao Tanaka memutuskan untuk mengundurkan diri, selain itu nama Toshiba juaga dihapus dari indeks saham dan penurunan penjualan yang signifikan (integrity-Indonesia.com, 14 September 2017).

Salah satu faktor penyebab adanya praktik manajemen laba di dalam perusahaan menurut teori agensi adalah karena terdapat perbedaan kepentingan antara pemilik perusahan, manajemen, dan pemerintah. Selain faktor tersebut, manajemen laba juga dipengaruhi oleh faktor lain, yaitu Perencanaan pajak (tax palnning). Perencanaan pajak (tax palnning) ini muncul karena adanya perbedaan kepentingan antara perusahaan dengan pemerintah. Perencanaan pajak adalah langkah awal dalam manajemen pajak. Dalam tahapan ini akan dilakukan pengumpulan dan penelitian terhadap peraturan perpajakan agar dapat diseleksi jenis tindakan penghematan pajak yang akan dilakukan. Pada umumnya perencanaan pajak ( $\operatorname{tax}$ planning) adalah untuk meminimumkan pembayaran pajak kepada pemerintah. Hubungan antara perencanaan pajak dengan manajemen laba ialah dengan adanya perencanaan pajak maka perusahaan akan cenderung melakukan manajemen laba (Yusrianti, 2015:14). Manajemen laba terus dilakukan untuk meminimalisasi laba sebagai penentu besarnya pajak yang harus dibayar kepada pemerintah.

Sejak tahun 2010 tarif pajak untuk $\mathrm{PPh}$ Badan adalah 25\%. Tarif ini pun dihitung dari penghasilan neto. Artinya, wajib pajak masih diberikan kemudahan dengan cara membiayakan biaya yang boleh menjadi pengurang. Selain itu, bagi perusahaan yang kepemilikan sahamnya dimiliki oleh publik sebesar $40 \%$, maka akan diberikan fasilitas penurunan tarif pajak atau diskon pajak sebesar 5\%. Maka perusahaan hanya berkewajiban untuk membayar pajak sebesar $20 \%$. Untuk memperoleh fasilitas tersebut, wajib pajak badan dalam negeri yang berbentuk perseroan terbuka harus memenuhi persyaratan yang telah ditentukan dalam Peraturan Pemerintah (PP) No. 77 Tahun 3013 kemudian diganti dengan Peraturan Pemerintah No. 56 Tahun 2015.

Dengan adanya fasilitas penurunan tarif pajak dapat mempengaruhi perilaku wajib pajak dalam melakukan perencanaan pajak. Maka dari itu, dalam penelitian ini peneliti melibatkan fasilitas penurunan tarif pajak sebagai variabel moderasi yang nantinya akan menguatkan atau melemahkan pengaruh perencanaan pajak terhadap manajemen laba. Dari latar belakang tersebut diatas, penulis melakukan penelitian yang berjudul "Pengaruh Perencanaan Pajak Terhadap Manajemen Laba Yang Dimoderasi Oleh Penurunan Tarif Pajak (Diskon Pajak)". 


\section{TINJAUAN PUSTAKA}

\section{Teori Keagenan}

Secara khusus Jensen dan Meckling pada tahun 1974 berusaha mendefinisikan hubungan agensi sebagai sebuah kontrak antara seseorang atau lebih meminta orang lain untuk melakukan jasa tertentu demi kepentingannya. Untuk itu pemilik perusahaan akan mendelegasikan wewenang untuk mengerjakan sesuatu yang seharusnya dilakukannya kepada orang lain yang dipilihnya atau disebut dengan manajer. Pendelegasian wewenang ini menjadi sebuah keharusan dalam hubungan agensi agar manajer mempunyai kesempatan yang luas untuk menjalankan tugasnya, sekaligus mempertanggungjawabkan apa yang telah dikerjakannya kepada pemilik perusahaan. Hubungan agensi ini harusnya dapat membuat perusahaan meningkat nilainya karena dikelola oleh orang yang mengetahui dan memahami bagaimana menjalankan usaha serta diawasi secara ketat oleh pemilik, namun yang terjadi justru sebaliknya. Namun, permasalahan agensi akan muncul apabila salah satu pihak mempunyai keinginan untuk memaksimalkan kesejahteraannya (moral hazard), meski harus merugikan pihak lain. Jika dalam satu transaksi bisnis yang sama, ada beberapa pihak mendapatkan lebih banyak informasi daripada pihak yang lainnya, maka kondisi tersebut dinyatakan sebagai asimetri informasi. Akibatnya pemilik tidak dapat mengawasi seluruh upaya yang dilakukan oleh agen. Hal tersebut mengakibatkan agen akan cenderung melakukan perilaku yang tidak semestinya (disfunctional behaviour) (Sulistyanto 2008).

\section{Manajemen Laba}

Menurut Sulistiawan, Januaris, dan Alvia (2011) istilah populer lainnya yang berkaitan dengan manajemen laba adalah creative accounting. Sampai dengan sekarang, beberapa penulis mendefinisikan manajemen laba secara berbeda-beda.

Menurut Amat, Oriol, dan Gowthorpe (2004), manajemen laba (creative accounting) merupakan transformasi informasi keuangan dengan menggunakan pilihan metode, estimasi dan praktik akuntansi yang diperbolehkan oleh standar akuntansi. Demikian juga dengan Myddelton (2009) yang menyatakan bahwa akuntan yang dianggap kreatif adalah akuntan yang menginterpretasikan area abu-abu untuk mendapatkan manfaat atau keuntungan dari hasil interpretasi tersebut. Jadi dengan harapan mendapatkan tujuan tertentu, mereka akan menginterpretasikan kebijakan akuntansi dengan cara tertentu juga sesuai keinginan mereka.

Selaras dengan definisi tersebut, sulistiawan (2003) sama mendefinisikan manajemen laba (creative accounting), yaitu aktivitas badan usaha untuk memanfaatkan teknik dan kebijakan akuntansi guna mendapatkan hasil yang diinginkan (Creative Accounting 2011:18-19).

Secara umum manajemen laba didefinisikan sebagai upaya manajer perusahaan dalam mengintervensi atau mempengaruhi informasi dalam laporan keuangan yang bertujuan untuk mengelabui stakeholder yang ingin mengetahui kinerja dan kondisi perusahaan. Istilah intervensi dan mengelabui ini yang digunakan sebagai dasar oleh sebagian pihak untuk menilai manajemen laba sebagai kecurangan. Namun pihak lain tetap menganggap bahwa aktivitas rekayasa manajerial ini bukan sebagai kecurangan. Alasannya, intervensi itu dilakukan manajer perusahaan dalam kerangka standar akuntansi, yaitu masih menggunakan metode dan prosedur akuntansi yang diterima dan diakui secara umum (Sulistyanto 2008:6).

\section{Perencanaan Pajak}

Menurut Rochmat Soemitro pajak adalah iuran rakyat kepada kas negara berdasarkan undang-undang (yang dapat dipaksakan) dengan tidak mendapat jasa timbal balik (kontaprestasi) yang langsung dapat ditunjukan dan yang digunakan untuk membayar pengeluaran umum. Kemudian definisi tersebut disempurnakan. Pajak adalah peralihan kekayaan dari pihak rakyat kepada kas negara untuk membiayai pengeluaran rutin dan "surplus"-nya digunakan untuk public saving yang merupakan sumber utama untuk membiayai public investment (Resmi 2017:1).

Adanya perbedaan kepentingan antara manajer dan pemerintah, sering kali membuat manajer melakukan berbagai cara agar dapat meminumumkan pembayaran pajak. Upaya dalam melakukan penghematan pajak secara legal dapat dilakuakn melalui manajemen pajak. Namun perlu diingat bahwa legalitas manajemen pajak tergantung dari instrumen yang dipakai. Legalitas baru dapat diketahui secara pasti setelah ada putusan pengadilan. Secara umum manajemen pajak dapat didefinisikan sebagai sarana untuk memenuhi kewajiban perpajakan dengan benar tetapi jumlah pajak yang dibayar dapat ditekan serendah mungkin untuk memperoleh laba dan 
likuiditas yang diharapkan (Sophar Lumbantoruan, 1996).

Menurut (Suandy 2011:6) Tujuan manajemen pajak dapat dibagi menjadi dua, yaitu :

1. Menerapkan peraturan perpajakan secara benar.

2. Usaha efisiensi untuk mencapai laba dan likuiditas yang seharusnya.

Tujuan tersebut dapat dicapai melalui fungsifungsi manajemen pajak yang terdiri dari perencanaan pajak (tax planning), pelaksanaan kewajiban perpajakan (tax implementation), dan penegndalian pajak (tax control).

Perencanaan pajak adalah langkah awal dalam manajemen pajak. Pada tahap ini dilakukan pengumpulan dan penelitian terhadap peraturan perpajakan agar dapat diseleksi jenis tindakan penghematan pajak yang akan dilakukan. Pada umumnya penekanan perencanaan pajak (tax planning) adalah untuk meminimumkan kewajiban pajak. Menurut Crumbley D. Larry, Friedman Jack P., dan Anders Susan B., 1994) menjelaskan bahwa perencanaan pajak analisis sistematis opsi penangguhan pajak yang ditujukan untuk meminimalkan kewajiban pajak pada periode saat ini dan masa depan (tax planning is the systematic analysis of deferring tax options aimed at the minimization of tax liability in current and future tax periods).

Untuk meminimumkan kewajiban pajak dapat dilakukan dengan berbagai cara, baik yang masih memenuhi ketentuan perpajakan (lawful) maupun yang melanggar peraturan perpajakan (unlawful). Istialh yang sering digunakan adalah tax avoidance dan tax evasion.

Perencanaan pajak umumnya selalu dimulai dengan meyakinkan apakah suatu transaksi atau fenomena terkena pajak. kalau fenomena tersebut terkena pajak, apakah dapat diupayakan untuk dikecilkan atau dikurangi jumlah pajaknya, selanjutnya apakah pembayaran pajak dimaksud dapat ditunda pembayarannya, dan lain sebagainya. Oleh karena itu setiap wajib pajak akan membuat rencana pengenaan pajak atas setiap tindakan (taxable events) secara seksama. Dengan demikian, bisa dikatakan bahwa perencanaan pajak adalah proses pengambilan faktor pajak yang relevan dan faktor non pajak yang material untuk menentukan apakah, kapan, bagaimana, dan dengan siapa (pihak mana) dilakukan transaksi, operasi, dan hubungan dagang yang memungkinkan tercapainya beban pajak pada tax events yang serendah mungkin dan sejalan dengan tercapainya tujuan perusahaan (Barry Spitz, 1983) (Suandy 2011:8).

\section{Tarif wajib Pajak Badan}

Tarif PPh Badan di Indonesia adalah 25\% dan berlaku sejak 2010. Sebelumnya tarif $\mathrm{PPh}$ Badan pernah mencapai 28\%. Tarif ini pun dihitung dari penghasilan neto. Artinya wajib pajak masih diberikan kelonggaran-kelonggaran dengan cara membiayakan biaya yang boleh menjadi pengurang. Jadi meskipun wajib pajak memiliki peredaran usaha yang besar belum tentu wajib pajak tersebut membayar pajak dengan jumlah besar. Selain itu, juga terdapat beberapa fasilitas dalam pengenaan PPh Badan di Indonesia. Yaitu pemberian diskon tarif sebesar 50\% dari tarif normal untuk wajib pajak dalam negeri dengan peredaran usahan Rp 50 miliar. Mereka diberikan pengurangan tarif dengan dikenakan $50 \%$ dari tarif 25\% untuk penghasilan sampai dengan Rp 4,8 miliar. Selain itu, pemberian diskon juga diberikan kepada Wajib Pajak Badan yang sudah go public sebesar 5\%, jadi Wajib Pajak Badan tersebut hanya dikenakan tarif sebesar 20\% saja. Pemberian tarif tersebut diatur dalam Peraturan Pemerintah Nomor 77 Tahun 2013 dan kemudian digantikan dengan Peraturan Pemerintah Nomor 56 Tahun 2015. Penurunan tarif atau diskon tersebut diberikan apabila Wajib Pajak Badan dalam negeri yang berbentuk perseroan terbuka telah memenuhi persyaratan sebagai berikut :

1. Paling sedikit $40 \%$ dari jumlah keseluruhan sahamyang disetor dicatat untuk diperdagangkan di Bursa Efek Indonesia (BEI).

2. Saham sebagaimana dimaksud dalam hurif a harus dimliki oleh paling sedikit 300 (tiga ratus) pihak.

3. Masing-masing pihak sebagaimana dimaskud dalam huruf $\mathrm{b}$, hany boleh memiliki saham kurang dari 5\% dari keseluruhan saham yang ditetapkan dan disetor penuh.

4. Ketentuan sebagaimana dimaksud dalam huruf $\mathrm{a}, \mathrm{b}$, dan c harus dipenuhi dalam waktu paling singkat 183 hari kalender dalam jangka waktu satu Tahun Pajak (https://www.ortax.org).

\section{Kerangka Pemikiran}

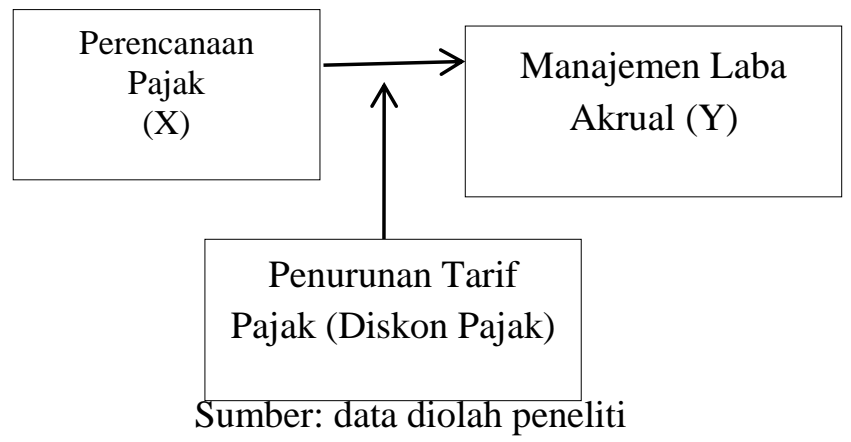


Pengembangan Hipotesis

\section{Pengaruh Perencanaan Pajak Terhadap manajemen Laba}

Hubungan antara perencanaan pajak terhadap manajemen laba bisa dijelaskan dengan teori agensi. Perencanaan pajak dilakukan karena adanya perbedaan kepentingan antara perusahaan dan pemerintah. Dimana perusahaan berusaha membayar pajak sekecil mungkin, sementara pemerintah mengharapkan penerimaan pajak semaksimal mungkin dari perusahaan.

Semakin tinggi perencanaan pajak maka akan semakin besar peluang untuk melakukan manajemen laba. Lestari, Kurnia, dan Yuniati (2018) menemukan hasil yang berbeda, dimana Perencanaan Pajak berpengaruh secara signifikan terhadap Manajemen Laba. Hal ini dikarenakan perusahaan melakukan perencanaan pajak bertujuan untuk melakukan penghematan pembayaran pajak yang akan dibayarkan kepada pemerinah. Perencanaan pajak yang dilakukan haruslah sesuai dengan ketentuan undang-undang perpajakan yang berlaku saat ini.

Sementara Wardani dan Santi (2018) meneliti bahwa Perencanaan Pajak tidak berpengaruh terhadap Manajemen Laba. Hal ini karena di dalam perusahaan manufaktur terdapat divisi atau departemen dengan masing-masing manajemen. Hal ini akan membuat kecenderungan bahwa manajemen akan mementingkan kepentingannya masing-masing, dalam hal ini untuk memperoleh bonus atau reward apabila menunjukan kinerja yang baik, sehingga manajemen laba yang dilakukan cenderung terjadi karena principal (pemilik perusahaan). Oleh karena itu, dirumuskan hipotesis kesatu sebagai berikut :

H1: Perencanaan Pajak berpengaruh signifikan terhadap manajemen laba

\section{Pengaruh Moderasi Penurunan Tarif Pajak Terhadap Hubungan Perencanaan Pajak dan Manajemen Laba}

Penurunan atau perubahan tarif pajak dapat mempengaruhi perilaku perencanaan pajak. Penurunan tarif tersebut diatur dalam Peraturan Pemerintah Nomor 56 Tahun 2015 dan Peraturan Pemerintah Nomor 77 Tahun 2013. Dimana bagi wajib pajak badan yang berbentuk Perseroan Terbuka dapat memperoleh fasilitas penurunan tarif pajak sebesar $5 \%$, dari $25 \%$ menjadi $20 \%$ tentunya setelah memnuhi persyaratan.

Penurunan tarif pajak akan mendorong perusahaan melakukan manajemen laba. Manajemen laba cenderung diakukan pada periode sebelum penurunan tarif pajak. Masri dan Martani
(2012) membuktikan bahwa hasil regresi empiris menunjukan pengaruh tax avoidance terhadap cost of debt adalah positif. Kreditur memandang tax avoidance tersebut sebagai resiko resiko sehingga perilaku tax avoidance justru meningkat cost of debt. Pada periode sebelum penurunan tarif pajak (tarif tinggi) menunjukan pengaruh tax avoidance yang lebih kecil. Hal ini menunjukan kreditur menganggap tax avoidance pada periode sebelum perubahan tarif merupakan bagian dari perencanaan pajak, sehingga justru mengurangi biaya utang. Bahkan hubungan total tax avoidance terhadap cost of debt setelah memperhatikan perubahan tarif negatif, sehingga pada periode sebelum penurunan tarif kreditur tetap menganggap tax sheltering terbukti mengurangi pajak sehingga menurunkan cost of debt.

Penurunan tarif pajak mendorong perusahaan melakukan manajemen laba pada penghasilan sebelum penurunan tarif pajak yang berarti dapat dirumuskan sebagai hipotesis kedua sebagai berikut:

H2: Moderasi Penurunan Tarif Pajak (Diskon Pajak) berhasil memoderasi hubungan perencanaan pajak terhadap manajemen laba.

\section{METODE PENELITIAN}

\section{Teknik Analisis Data}

Metode yang digunakan dalam pengujian hipotesa ini adalah statistik deskriptif. Statistik deskriptif dilakukan untuk mengetaui deskripsi atau gambaran mengenai suatu data yang dapat dilihat dari nilai rata-rata (mean), standar deviasi, nilai maksimum dan minimum yang bertujuan untuk mengetahui distribusi data yang menjadi sampel dalam penelitian (Ghozali, 2011:19). Program yang digunakan untuk menganalisis data dalam penelitian ini adalah program eviews.

\section{Populasi dan Sampel}

Populasi yang digunakan dalam penelitian ini yaitu perusahaan LQ45 yang terdaftar di Bursa Efek Indonesia (BEI) pada tahun 2017-2018. Teknik pengumpulan sampel yang digunakan dalam penelitian ini adalah purposive sampling, metode pengambilan sampel yang menggunakan kriteria tertentu sesuai tujuan penelitian. Berikut adalah kriteria sampel yang akan digunakan adalah sebagai berikut :

1. Perusahaan yang terdaftar di LQ45 periode tahun 2017-2018

2. Perusahaan yang tidak termasuk kedalam jenis industri keuangan. Hal ini ditetapkan karena 
jenis industri keuangan sangat rentan terhadap regulasi serta memiliki perbedaan karakteristik akrual dibandingkan jenis industri lainnya.

3. Perusahaan yang tidak termasuk kedalam jenis industri perhotelan, travel, transportasi, dan real estate,. Hal ini ditetapkan karena perusahaanperusahaan yang termasuk kedalam industri tersebut memiliki karakteristik keuangan yang berbeda dengan jenis industri perdagangan dan manufaktur.

4. Perusahaan yang tidak termasuk kedalam jenis industri konstruksi. Hal ini dikarenakan jenis industri konstruksi terkait dengan pajak final dan tidak relevan terhadap variabel independen yang diteliti.

5. Memiliki data keuangan yang lengkap dari tahun 2017-2018 secara berturut-turut.

\section{Variabel Penelitian}

Variabel yang digunakan dalam penelitian ini terbagi 3 (tiga) yaitu Perencanaan Pajak sebagai variabel independen, Penurunan Tarif Pajak (Diskon Pajak) sebagai variabel moderasi, serta manajemen laba akrual sebagai variabel dependen.

\section{Operasionalisasi Variabel}

\section{Perencanaan Pajak (X)}

Perencanaan pajak adalah langkah awal dalam manajemen pajak. Pada tahap ini dilakukan pengumpulan dan penelitian terhadap peraturan perpajakan agar dapat diseleksi jenis tindakan penghematan pajak yang akan dilakukan. Pada umumnya penekanan perencanaan pajak (tax planning) adalah untuk meminimumkan kewajiban pajak. Menurut Crumbley D. Larry, Friedman Jack P., dan Anders Susan B., 1994) menjelaskan bahwa perencanaan pajak adalah analisis sistematis opsi penangguhan pajak yang ditujukan untuk meminimalkan kewajiban pajak pada periode saat ini dan masa depan (tax planning is the systematic analysis of deferring tax options aimed at the minimization of tax liability in current and future tax periods). Mengacu pada penelitian Wardani dan Santi (2018), perencanaan pajak diukur dengan Tax Retention Rate (TRR) atau tingkat retensi pajak dengan rumus sebagai berikut :

$$
\mathrm{TRR}=\frac{\text { Net }_{\text {Income }}}{\text { Pretax } \operatorname{Income}(E B I T)_{i t}}
$$

Keterangan :

$\mathrm{TRR}_{\mathrm{it}}=$ Tax Retention Rate (tingkat retensi pajak) perusahaan i pada tahun $\mathrm{t}$

$\begin{array}{rlr}\text { Net Income }_{\mathrm{it}} & =\begin{array}{l}\text { Laba } \\ \text { perusahaan i persih } \\ \text { tahun t }\end{array} \\ \text { Pretax Income }(\text { EBIT) })_{\text {it }}= & \begin{array}{l}\text { Laba sebelum pajak } \\ \text { perusahaan i pada } \\ \text { tahun t }\end{array}\end{array}$

2. Penurunan Tarif Pajak (Diskon Pajak)

Penurunan tarif atau diskon tersebut diberikan apabila Wajib Pajak Badan dalam negeri yang berbentuk perseroan terbuka telah memenuhi persyaratan sebagai berikut :

a. Paling sedikit $40 \%$ dari jumlah keseluruhan sahamyang disetor dicatat untuk diperdagangkan di Bursa Efek Indonesia (BEI).

b. Saham sebagaimana dimaksud dalam hurif a harus dimliki oleh paling sedikit 300 (tiga ratus) pihak.

c. Masing-masing pihak sebagaimana dimaskud dalam huruf $b$, hany boleh memiliki saham kurang dari 5\% dari keseluruhan saham yang ditetapkan dan disetor penuh.

d. Ketentuan sebagaimana dimaksud dalam huruf $\mathrm{a}, \mathrm{b}$, dan $\mathrm{c}$ harus dipenuhi dalam waktu paling singkat 183 hari kalender dalam jangka waktu satu Tahun Pajak (https://www.ortax.org).

Penurunan tarif pajak diukur menggunakan variabel dummy. Dimana, bagi perusahaan terbuka yang kepemilikan sahamnya dimiliki oleh masyarakat atau publik sebanyak $40 \%$ lebih dan telah memenuhi persyaratan maka akan diberikan skor 1, lalu skor 0 untuk perusahaan yang kepemilikan sahamnya dimiliki oleh publik kurang dari $40 \%$.

3. Manajemen Laba

Menurut Amat et al (2004) manajemen laba (creative accounting) merupakan transformasi informasi keuangan dengan menggunakan pilihan metode, estimasi dan praktik akuntansi yang diperbolehkan oleh standar akuntansi. Penelitian ini menggunakan discretionary accruals sebagai proksi manajemen laba yang menggunakan model Modified Jones (Jones Modifikasian) (Dechow at $a l$, 1995). Formula yang digunakan adalah cara alternatif yang lebih mudah untuk mencari nilai discretionary accruals (Cohen et al., 2008), yaitu:

$$
\begin{aligned}
\frac{T A_{i t}}{\text { Assets }_{i t-1}=k_{1 t}} & +\frac{1}{\text { Assets }_{i t-1}} \\
& +k_{2} \frac{\left(\Delta R V_{i t}-\Delta A R_{i t}\right)}{\text { Assets }_{i t-1}} \\
& +k_{2} \frac{P P E_{i t}}{\text { Assets }_{i t-1}}+\varepsilon_{i t} \cdots
\end{aligned}
$$


Nilai residual dari estimasi di atas merupakan discretionary accrual.

Keterangan :

\begin{tabular}{|c|c|}
\hline $\mathrm{A}_{\mathrm{it}}$ & $\begin{aligned} &= \text { Total akrual perusahaan i pada tahun } \\
& \mathrm{t} \text { (dimana } \mathrm{TA}_{\mathrm{it}}=\text { Laba tahun } \\
& \text { berjalan - Aliran kas dari kegiatan } \\
& \text { operasi) }\end{aligned}$ \\
\hline Assets $_{\text {it-1 }}$ & $\begin{array}{l}=\text { Total aset perusahaan i pada tahun } \mathrm{t}- \\
1\end{array}$ \\
\hline$\Delta \mathrm{REV}_{\mathrm{t}}$ & $\begin{aligned}= & \text { Perubahan pendapatan perusahaan } \mathrm{i} \\
& \text { pada tahun } \mathrm{t}\end{aligned}$ \\
\hline$\Delta \mathrm{AR}_{\mathrm{t}}$ & $=\begin{array}{l}\text { Perubahan piutang dagang } \\
\text { perusahaan i pada tahun } \mathrm{t}\end{array}$ \\
\hline $\mathrm{PPE}_{\mathrm{it}}$ & $\begin{aligned} & \text { Aset tetap (pabrik, properti, dan } \\
& \text { peralatan) perusahaan i pada tahun } \mathrm{t}\end{aligned}$ \\
\hline
\end{tabular}

\section{HASIL PENELITIAN DAN PEMBAHASAN}

\section{Hasil Statistik \\ Analisis Statistik Deskriptif}

Statistik deskriptif dilakukan untuk mengetaui deskripsi atau gambaran mengenai suatu data yang dapat dilihat dari nilai rata-rata (mean), standar deviasi, nilai maksimum dan minimum yang bertujuan untuk mengetahui distribusi data yang menjadi sampel dalam penelitian (Ghozali, 2011:19). Program yang digunakan untuk menganalisis data dalam penelitian ini adalah program eviews.

\section{Tabel 4.1}

\section{Hasil Pengujian Statistik Deskriptif}

\begin{tabular}{|c|c|c|}
\hline & MLB & PTP TRPT \\
\hline Mean & -0.008385 & 0.7008660 .4347830 .33964 \\
\hline Median & -0.006996 & 0.7300880 .000 \\
\hline Maximum & 0.157678 & 17100000001705 \\
\hline $\begin{array}{l}\text { Minimum } \\
\text { Std. }\end{array}$ & -0.213934 & 0.1404250 .0000000 .000 \\
\hline Deviasi & 0.068583 & 0.2590250 .5012060 .4328 \\
\hline Sumber & r : Hasil Ola & h Data Eviews 9.0 \\
\hline \multicolumn{3}{|c|}{ Keterangan : } \\
\hline MLB $: \mathrm{N}$ & \multicolumn{2}{|c|}{ : Manajemen Laba } \\
\hline TRR & \multicolumn{2}{|c|}{ Perencanaan Pajak } \\
\hline PTP & \multicolumn{2}{|c|}{ : Penurunan Tarif Pajak (Diskon Pajak) } \\
\hline$: \mathrm{Ir}$ & \multicolumn{2}{|c|}{ Interaksi antaran TRR dan PTP } \\
\hline
\end{tabular}

Tabel di atas menunjukan deskripsi variabelvariabel secara statistik. Hasil dari statistik deskriptif dapat dijelaskan sebagai berikut :

1. MLB (Manajemen Laba ) memiliki nilai ratarata (mean) sebesar -0.008385 dengan nilai tengah (median) -0.006996. Nilai tertinggi (maximum) untuk MLB adalah 0.157678 pada PT. AKR Corporindo Tbk dan nilai terendahnya (minimum) untuk MLB adalah 0.213934 pada PT. XL Axiata Tbk. Serta nilai std. deviasi untuk MLB adalah 0.068583 .

2. TRR (Perencanaan Pajak) memiliki mean sebesar 0.700866 dan median sebesar 0.730088 . Nilai maximum untuk TRR adalah 1.705517 pada PT. AKR Corporindo Tbk. serta nilai minimum nya adalah 0.140425 pada PT. Sawit Sumbermas Sarana Tbk. Serta nilai std. deviasi untuk TRR adalah 0.259025 .

3. PTP (Penurunan Tarif Pajak (Diskon Pajak)) memiliki mean sebesar 0.434783 dengan median sebesar 0.000000. Nilai maximum untuk PTP adalah 1.000000 pada PT. Adaro Energy Tbk., PT. AKR Corporindo Tbk., PT. Astra International Tbk., PT. Indofood Sukses Makmur Tbk., PT. Indocement Tunggal Prakarsa Tbk., PT. Kalbe Farma Tbk., PT. Matahari Department Store Tbk., PT. Perusahaan Gas Negara Tbk., PT. Semen Indonesia Tbk., PT. Telekomunikasi Indonesia Tbk., dan nilai minimum sebesar 0.000000 pada PT. Aneka Tambang Tbk., PT. XL Axiata Tbk., PT. Gudang Garam Tbk., PT. HM Sampoerna Tbk., PT. Indofood CBP Sukses Makmur Tbk., PT. PT. Vale Indonesia Tbk., PT. Jasa Marga (Persero) Tbk., PT. Media Nusantara Citra Tbk., PT. Bukit Asam Tbk., PT. Surya Citra Media Tbk., PT. Sri Rejeki Isman Tbk., PT. Sawit Sumbermas Sarana Tbk., PT. Unilever Indonesia Tbk. serta nilai st. deviasi untuk PTP sebesar 0.501206.

4. TRPT (Interaksi antara TRR dan PTP) memiliki mean sebesar 0.339646 dan median sebesar 0.000000. Nilai maximum untuk TRPT sebesar 1.705517 pada PT. AKR Corporindo Tbk. dan nilai minimum untuk TRPT sebesar 0.000000 pada PT. Aneka Tambang Tbk., PT. XL Axiata Tbk., PT. Gudang Garam Tbk., PT. HM Sampoerna Tbk., PT. Indofood CBP Sukses Makmur Tbk., PT. PT. Vale Indonesia Tbk., PT. Jasa Marga (Persero) Tbk., PT. Media Nusantara Citra Tbk., PT. Bukit Asam Tbk., PT. Surya Citra Media Tbk., PT. Sri Rejeki Isman Tbk., PT. Sawit Sumbermas Sarana Tbk., PT. Unilever Indonesia Tbk. Nilai std. deviasi untuk TRPT adalah 0.432891.

\section{Model Regresi Data Panel}

Penelitian ini menggunakan analisis regresi data panel dengan menggunakan pengujian comman effectyang menggunakan program olah 
data Eviews 9.0. regresi data panel digunakan untuk menguji pengaruh antara variabel independen terhadap variabel dependen, kemudian akan diuji secara empirik untuk melihat pengaruh Perencanaan Pajak, Penurunan Tarif Pajak (Diskon Pajak) terhadap Manajemen Laba pada perusahaan yang terdaftar di LQ45 tahun 2017-2018. Hasil regresi data panel akan ditunjukan pada tabel 2 dibawah ini :

Tabel 4.2

Hasil Signifikansi Common Effect

\begin{tabular}{|c|c|c|c|}
\hline Variable & Coefficient & $\begin{array}{cr}\text { Std. } & \mathrm{t}- \\
\text { Error } & \text { Statistic }\end{array}$ & Prob. \\
\hline $\mathrm{C}$ & \multicolumn{2}{|c|}{0.0239160 .0137411 .740451} & 0.0891 \\
\hline TRR & \multicolumn{2}{|c|}{$-0.0622930 .0223902 .782137$} & 0.0081 \\
\hline PTP & \multicolumn{2}{|c|}{$-0.1520300 .0204447 .436306$} & 0.0000 \\
\hline TRPT & \multicolumn{2}{|c|}{0.2240910 .0283717 .898546} & 0.0000 \\
\hline
\end{tabular}

Sumber :Hasil Olah Data Eviews 9.0

Berdasarkan hasil analisis regresi data panel pada tabel 2 di atas, diperoleh koefisien (coefficient) untuk independen Perencanaan Pajak (TRR), variabel moderasi Penurunan Tarif Pajak (Diskon Pajak) (PTP), dan interaksi antara TRR dan PTP (TRPT). Berikut adalah persamaan regresi setelah diperoleh dari hail penelitian pada tabel 2 : $\mathrm{Y}=0.023916-0.062293_{\mathrm{TRR}}-0.152030_{\mathrm{PTP}}+$ $0.224091_{\mathrm{TRPT}}+\varepsilon$

Keterangan :

$\mathrm{Y} \quad=$ Manajemen Laba (MLB)

TRR = Perencanaan Pajak

PTP = Penurunan Tarif Pajak

TRPT = Interaksi antara TRR dan TRPT

$\varepsilon \quad=$ Error

Berdasarkan persamaan regresi di atas, dapat dijelaskan sebagai berikut :

1. Konstanta (c) sebesar 0.023916 menyatakan bahwa jika variabel Perencanaan Pajak, PenurunanTarif Pajak (Diskon Pajak), dan variabel interaksi (TRPT) bernilai di atas 0, maka Manajemen Laba sebesar 0.23916.

2. Koefisien Perencanaan Pajak (TRR) bernilai 0.062293 yang artinya setiap kenaikan 1 satuan variabel Perencanaan Pajak akan mengakibatkan menurunnya variabel Manajemen Laba sebesar 0.062293 dengan asumsi variabel independen lainnya dianggap tetap.

3. Koefisien Penurunan Tarif Pajak (PTP) bernilai -0.152030 , yang artinya setiap kenaikan 1 satuan variabel Penurunan Tarif Pajak, akan mengakibatkan menurunnya variabel Manajemen Laba sebesar 0.152030 dengan asumsi variabel independen lainnya dianggap tetap.

4. Koefisien interaksi antara Perencanaan Pajak (TRPT) atau Moderasi bernilai 0.224091 yang artinya setiap perubahan 0.224091 dari TRPT, maka akan Manajemen Laba akan berubah sebesar 0.224091 .

\section{Pembahasan}

\section{Manajemen Laba Akrual}

1. Pengaruh Perencanan Pajak Terhadap Manajemen Laba

Perencanaan pajak dalam penelitian ini diukur TRR (Tax Retention Rate). Hasil penelitian dalam tabel 4.8 menunjukan bahwa Perencanaan Pajak berpengaruh signifikan terhadap Manajemen Laba dengan arah atau hubungan yang negatif. Artinya semakin kecil Perencanaan Pajak (TRR) nya, akan semakin besar Tax Avoidance nya (TA), maka akan semakin meningkatkan manajemen laba. Hal ini disebabkan karena perusahaan tidak ingin membayar pajak yang terlalu besar. Penelitian ini sejalan dengan penelitian yang dilakukan oleh Lestari, Kurnia, dan Yuniati (2018) yang menyatakan bahwa perencanaan pajak berpengaruh terhadap manajemen laba, namun tidak sejalan pada hubungan arah koefisien. Hal tersebut terjadi karena sampel pada perusahaan ini berbeda dengan penelitian sebelumnya. Sampel pada penelitian ini menggunakan perusahaan yang terdaftar di LQ45, dimana tujuan perencanaan pajak dan manajemen labanya juga mungkin berbeda dengan perusahaan sampel pada penelitian sebelumnya. Namun penelitian ini tidak sejalan dengan penelitian yang dilakukan oleh Wardani dan Santi (2018) yang menyatakan bahwa perencanaan pajak tidak berpengaruh terhadap manajemen laba.

2. Pengaruh Moderasi Penurunan Tarif Pajak (Diskon Pajak) Terhadap Hubungan Perencanaan Pajak dan Manajemen Laba

Penurunan (Diskon Pajak) atau perubahan tarif pajak dapat mempengaruhi perilaku perencanaan pajak. Penurunan tarif tersebut diatur dalam Peraturan Pemerintah Nomor 56 Tahun 2015 dan Peraturan Pemerintah Nomor 77 Tahun 2013. Dimana bagi wajib pajak badan yang berbentuk Perseroan Terbuka dapat memperoleh fasilitas penurunan tarif pajak sebesar 5\%, dari $25 \%$ menjadi $20 \%$ tentunya setelah memnuhi persyaratan. Penurunan Tarif Pajak (Diskon Pajak) diukur menggunakan variabel dummy. 
Berdasarkan hasil penelitian, diskon pajak terbukti memoderasi hubungan perencanaan pajak dan manajemen laba. Artinya diskon pajak memperlemah hubungan perencanaan pajak terhadap manajemen laba. Hal ini mengindiksikan bahwa ketika nilai TRR semakin besar, maka TA nya kecil, dengan demikian akan menurunkan manajemen laba yang dilakukan oleh perusahaan. Hal ini disebabkan karena ketika suatu perusahaan mendapatkan diskon pajak, maka perusahaan tidak melakukan perencanaan pajak lagi karena tarif pajaknya sudah rendah.

Hal tersebut didukung oleh penelitian yang dilakukan oleh Masri dan Martani (2012) yang menyatakan bahwa penurunan tarif pajak berhasil memoderasi penghindaran pajak (tax avoidance) ke arah yang positif.

\section{KESIMPULAN DAN SARAN}

\section{Kesimpulan}

Tujuan penelitian ini adalah untuk mengetahui Pengaruh Perencanaan Pajak terhadap Manajemen Laba yang Dimoderasi oleh Penurunan Tarif Pajak (Diskon Pajak) pada perusahaan yang terdaftar di LQ45 secara berturut-turut dari tahun 2017-2018. Dari hasil penelitian terdapat 23 sampel perusahaan LQ45 pada periode 2017-2018 maka dapat ditarik kesimpulan sebagai berikut :

1. Perencanaan pajak terbukti berpengaruh signifikan terhadap manajemen laba dengan arah hubungan koefisien negatif. Artinya bahwa nilai TRR yang kecil, sementara nilai Tax Avoidance (TA) nya besar, maka perusahaan akan semakin menaikkan perilaku manajemen laba. Hal tersebut berarti perusahaan akan melakukan manajemen laba untuk mendapatkan pembayaran pajak yang rendah. Walaupun pengaruhnya lemah, tetapi masih banyak faktor yang menyebabkan suatu perusahaan melakukan manajemen laba.

2. Penurunan tarif pajak (diskon pajak) berhasil memoderasi hubungan perencanaan pajak dan manajemen laba. Penurunan tarif pajak (diskon pajak) memperlemah hubungan perencanaan pajak dan manajemen laba, hal ini mengindikasi bahwa dengan adanya moderasi yang memperlemah, maka akan menurunkan manajemen laba. Hal ini terjadi karena ketika perusahaan sudah mendapatkan diskon pajak, maka perusahaan tersebut tidak lagi melakukan perencanaan pajak karena tarif pajaknya sudah rendah.

\section{Saran}

Berdasarkan hasil pembahasan di atas, maka dapat dikemukakan beberapa saran untuk peneliti selanjutnya, perusahaan, pemerintah, dan investor. Berikut adalah saran yang dapat diberikan :

\section{Bagi Peneliti Selanjutnya}

1. Dalam penelitian ini hanya ada satu variabel dan satu moderasi. Diharapkan untuk peneliti selanjutnya dapat menambahkan variabel x yang berpengaruh.

2. Selain daripada itu, dalam penelitian ini untuk mengukur manajemen laba menggunakan model dari Cohen, diharapkan untuk peneliti selanjutnya dapat menggunakan model-model yang lainnya untuk mengukur manajemen laba seperti Modofied Jones Model, Kanszik Model, atau Performance-Matched Discresionary Acrual Model.

3. Menggunakan periode pengamatan yang lebih panjang, karena semakin panjang interval waktu pengamatan, maka akan semakin akurat dan besar kesempatan untuk memperoleh informasi yang akan digunakan.

\section{Bagi Perusahaan}

Perusahaan hendaknya melakukan perencanaan pajak yang lebih baik lagi dan sesuai dengan peraturan perpajakan. Hal tersebut bisa dilakukan melalui penganalisaan informasi yang ada secara teliti, seperti mengetahui dan mengikuti perkembangan peraturan perpajakan terbaru yang berlaku melalui berita pajak, website resmi Dirjen Pajak, surat edaran dari Dirjen Pajak, dan informasi yang lainnya. Hal tersebut dapat menghindari kesalahan yang mungkin tidak sengaja dilakukan oleh perusahaan, karena kesalahan perpajakan dapat dikenakan sanksi, artinya hal tersebut merupakan pemborosan. Dengan perencanaan pajak yang baik dan sehat, kinerja perusahaan akan baik dimata pimpinan dan investor.

\section{Bagi Pemerintah}

Bagi pemerintah, hal ini bisa menjadi acuan untuk mengevaluasi peraturan perpajakan yang telah dibuat.

\section{Bagi Investor}

Bagi calon investor dan investor, sebaiknya lebih teliti sebelum melakukan investasi. Sebaiknya sebelum melakukan investasi, investor melakukan analisis terhadap laporan keuangan yang disajikan oleh perusahaan. Karena laporan keuangan yang disajikan, belum tentu mencerminkan kinerja perusahaan yang sebenarnya. Investor harus 
waspada terhadap praktik manajemen laba yang mungkin dilakukan oleh perusahaan.

\section{DAFTAR PUSTAKA}

(Ortax), O. \&. (2019, November 20). Peraturan Pemerintah - 56 Tahun 2015. Retrieved from ortax.org:

https://www.ortax.org/ortax/?mod=aturan\&p age $=$ show $\& \mathrm{id}=15852 \& \mathrm{hlm}=$

Aditama, F., \& Purwaningsih, A. (2014). Pengaruh Perencanaan Pajak terhadap Manajemen Laba Pada Perusahaan Nonmanufaktur yang Terdaftar di Bursa Efek Indonesia. Modus, 26(1), 33-50.

Azizah, W. (2017). Opportunistic Perspective off Accrual and Real Earnings Management in Indonesia. IOSR Journal of Business and Management, 19(11), 1-5.

Cohen, D., \& Zarowin, P. (2008). Economic Consequences of Real and Accrual-Based Earnings Management Activities. Leonard Ster School of Business \& New York University, 0-42.

Dechow, P. M., Sloan, R. G., dan Sweeney, A. P. (1995). Detecting Earnings Management. The Accounting Review. Vol. 70, No.2. Hal: 193-225.

Dechow, P. M., Sloan, R. G., \& Sweeney, A. P. (1996). Causes and Cosequences of Earnings Manipulation: An Analysis of Firms Subject to Enforcement Actions by the SEC. Contemporary Accounting Research, Vol. 13, No. 1. pp 1-36.

Dunia, K. J. (2019, November 17). Laba Toyota Anjlok untuk Pertama Kali dalam 5 Tahun. Retrieved from kompas.com: https://money.kompas.com/read/2017/05/11/ 100200826/laba.toyota.anjlok.untuk.pertama. kali.dalam.5.tahun

Ferdinand, A. (2014). Metode Penelitian Manajemen . Semarang: Seri Pustaka Kunci.

Fitriany, L. C. (2016). Pengaruh Aset Pajak Tangguhan, Beban Pajak Tangguhan, dan Perencanaan Pajak terhadap Manajemen Laba. JOM Fekon, 3(1), 1150-1163.

Ghozali, I. (2011). Aplikasi Analisis Multivariate dengan Program SPSS (5 ed.). Semarang: Badan Penerbit Universitas Diponegoro.

Ghozali, I. (2016). Aplikasi Analisis Multivariate dengan Program IMB SPSS 23 (8 ed.). Semarang: Badan Penerbit Universitas Diponegoro.
Ghozali, I. (2018). Aplikasi Analisis Multivariate Dengan Program IMB SPSS 25. Semarang: Badan Penerbit Universitas Diponegoro.

Hamijaya, M. (2015). Pengaruh Insentif Pajak Terhadap manajemen Laba saat Terjadi Penurunan Tarif Pajak Penghasilan Badan Pada Perusahaan manufaktur yang Terdaftar di Bursa Efek. Jurnal Akuntansi Bisnis, 14(27), 1-28.

Jahja, S. A., \& Iqbal, M. (2012). Analisis Perbandingan Kinerja Keuangan Perbankan Syariah dengan Perbankan Konvensional. Episteme : Jurnal Pengembangan Ilmu Keislaman, 7(2), 338-360.

Jensen, M. C., \& Mwckling, W. H. (1976). Theory of the Firm : Managerial Behavior, agency Cost, and Ownership Structure. Journal of Financial Economics, Vol. 3, No. 4 pp305360

Lestari, D. S., Kurnia, I., \& Yuniati. (2018). Pengaruh Perencanaan Pajak dan Ukuran Perusahaan terhadap Manajemen Laba. Jurnal Ilmiah MEA (Manajemen, Ekonomi, dan Akuntansi), 2(3), 129-150.

Lubis, I., \& Suryani. (2018). Pengaruh TAx Planning, Beban Pajak Tangguhan, dan Ukuran Perusahaan terhadap Manajemen Laba. Jurnal Akuntansi dan Keuangan, 7(1), 41-58.

Masri, I., \& Martani, D. (2012). Pengaruh Tax avoidance terhadap Cost of Debt. Simposium Nasional Akuntansi XV, 1-27.

Negara, A. R., \& Saputra, I. (2017). Pengaruh Perencanaan Pajak dan Beban Pajak Tangguhan terhadap Manajemen Laba. EJurnal Akuntansi Universitas Udayana, 20(3), 2045-2072.

Pajak, D. J. (2019, September 10). Fasilitas Penurunan Tarif Pajak Penghasilan Bagi Wajib Pajak Badan Dalam Negeri Berbentuk Perseroan Terbuka. Retrieved from pajak.go.id:

https://www.pajak.go.id/id/fasilitaspenurunan-tarif-pajak-penghasilan-bagiwajib-pajak-badan-dalam-negeri-berbentukperseroan

Pujiastuti, L. (2019, November 10). Kasus Skandal Keuangan, CEO Toshiba Mundur. Retrieved from detikcom: https://finance.detik.com/industri/d2972287/kasus-skandal-keuangan-ceotoshiba-mundur

Resmi, S. (2017). Perpajakan : Teori dan Kasus. Jakarta: Salemba Empat. 
Saputra, Y. (2018). Pengaruh Perencanaan Pajak, Beban Pajak Tangguhan, dan Leverage terhadap Praktik Manajemen Laba. Jurnal Ekobis Dewantara, 1(6), 155-170.

Suandy, E. (2011). Perencanaan Pajak. Jakarta: Salemba Empat.

Sugiono. (2017). Metode Penelitian : Kuantitatif, Kualitatif, dan R\&D. Bandung: Alfabeta.

Sulistiawan, D., Januaris, Y., \& Alvia, L. (2011). Creative Accounting. Jakarta: Salemba Empat.

Sulistyanto, S. (2008). Manajemen Laba : Teori dan Model Empiris. Jakarta: PT. Grasindo.

Sutrisno, M., Sari, I. A., \& Astuti, Y. P. (2018). Pengaruh Perencanaan Pajak dan Insentif Non Pajak terhadap Manajemen LabaPada Perusahaan Manufaktur yang Terdaftar di Bursa Efek Indonesia Tahun 2013-2017. Permana, 10(1), 132-148.

Wardani, K. D., \& Santi, D. K. (2018). Pengaruh Tax Planning, Ukuran Perusahaan, Coporate Socil Responsibility (CSR) terhadap Manajemen Laba. Jurnal Akuntansi, 6(1), 11-24.

www.idx.co.id 